\title{
Trends and Interannual Variability of Satellite-Based Wind and Sea Surface Temperature over the Southern Ocean in the Recent Decade
}

\author{
Shailesh Mohan Pednekar \\ Earth System Sciences Organization (ESSO), Ministry of Earth Sciences (MoES), Government of India, National \\ Centre for Antarctic and Ocean Research (NCAOR), Vasco-da-Gama, India \\ Email: shailesh@ncaor.gov.in, shailesh22@yahoo.com
}

Received 10 January 2015; accepted 7 February 2015; published 11 February 2015

Copyright (C) 2015 by author and Scientific Research Publishing Inc. This work is licensed under the Creative Commons Attribution International License (CC BY). http://creativecommons.org/licenses/by/4.0/

(c) $\underset{\mathrm{EY}}{\mathrm{F}}$ Open Access

\section{Abstract}

Using satellite-based 10-m surface wind (SW), wind stress (WS) and sea surface temperature (SST) anomalies, trends and inter-annual variability during 1993 and 2008 over the Southern Ocean (SO) are addressed. The climatological mean (16 years average) indicates that negative wind stress curl diminished (enhanced) between $40^{\circ} \mathrm{S}$ and $60^{\circ} \mathrm{S}$ zonal strap region coincide with weak (strong) SW and warm (cold) SST anomaly during January (July). Annual climatology indicates that strong region of SW divides warmer waters northward with positive wind stress curl (WSCL) and colder waters southward with negative WSCL. The time series anomalies are smoothened with a 12-month running mean filter. The filtered area-mean time series anomalies of zonal and meridional component of SW and SST have linear trends of $-0.0005 \pm 0.0003 \mathrm{~m} / \mathrm{s} / \mathrm{decade}, 0.0012 \pm 0.0002$ $\mathrm{m} / \mathrm{s} /$ decade and $-0.00005^{\circ} \mathrm{C} \pm 0.0001^{\circ} \mathrm{C} /$ decade, respectively. The $\mathrm{SW}$ anomalies show an increasing trend of $0.0013 \pm 0.0002 \mathrm{~m} / \mathrm{s} / \mathrm{decade}$, with the meridional (zonal) component exhibiting an increasing (decreasing) trend. The meridional component plays a critical role in heat transfer through atmospheric circulation. The WS and wind stress divergence exhibit increasing trends whereas wind stress curl shows a decreasing trend. The SST fluctuates close to zero with repeated high and low peaks at an interval of 2 - 3 years. We address the interannual variability by performing EOF analysis on SW, WS, WSCL and SST anomalies which have been passed through a 12-month running mean filter. EOF-1 spatial pattern portrays low variances south of $40^{\circ} \mathrm{S}$ in $\mathrm{SW}$ between $25^{\circ} \mathrm{E}$ and the Drake Passage whereas in WS it is confined to Pacific Ocean sector of the SO. EOF-2 pattern exhibits high variability along the ACC, which is pronounced in the central Indian sector of the SO in SW and Pacific Ocean sector of the SO in WS. The time coefficient (SW, WS and WSCL) of EOF-1 (EOF-2) is correlated with reversed (actual) Antarctic Oscillation (AAO) index. The EOF-1 of SST shows high variance in the Indian sector south of $55^{\circ} \mathrm{S}$ and in the south Pacific 
sector of the SO. The corresponding time coefficient function indicates an inverse relationship with AAO index. EOF-2 of SST shows dipole structure of high variance in the Pacific Ocean sector of the SO; high positive variance is also evident in Indian sector. The time coefficient of EOF1 (EOF-2) is correlated with reversed AAO (Nino 3.4) index, with the earlier (latter) leading the former by 4 (9) months. Based on the EOF analyses, it can be inferred that AAO and Nino indices play an important role in modulating SW and SST changes in the SO.

\section{Keywords}

\section{Southern Ocean, Trends, Interannual Variability}

\section{Introduction}

The Southern Ocean (SO) is one of the largest sectors of the world oceans. It plays a key role in the climatic system on the Earth through its complex circulation induced by interconnection of three ocean basins at high southern latitude and strong air-sea interaction on seasonal and interannual time scales. The SO encompasses the Antarctic Circumpolar Current (ACC) around Antarctic continent, and also is characterized by basins and ridges with complex bottom topography (Figure 1).

The West Wind Drift reveals strong seasonality according to recent investigations; the NCEP-NCAR sea level atmospheric pressure at $65^{\circ} \mathrm{S}$ exhibits a climatic tendency of $-0.166 \pm 0.039 \mathrm{hPa} \cdot \mathrm{yr}^{-1}$ from 1957 to 1998 and $-0.177 \pm 0.062 \mathrm{hPa} \cdot \mathrm{yr}^{-1}$ from 1969 to 1998 . The negative tendency weakens with time to $-0.123 \pm 0.221 \mathrm{hPa} \cdot \mathrm{yr}^{-1}$ from 1979 to 1993 [1]. The surface air temperature estimated from infrared satellite data suggests a trend of $-0.042 \pm 0.067^{\circ} \mathrm{C}^{\cdot} \mathrm{yr}^{-1}$ [2] from 1979 to 1998 . These climatic variations have an effect on the position of the SubAntarctic and Polar Fronts [3]-[8] etc. and consequently on the ACC and its intensity [9].

In recent decades the importance of climate signals in the SO has been narrated in many studies by the researchers. For instance the trend for the Southern Hemisphere is reported to be $-0.3 \% \pm 0.5 \%$ per decade for sea

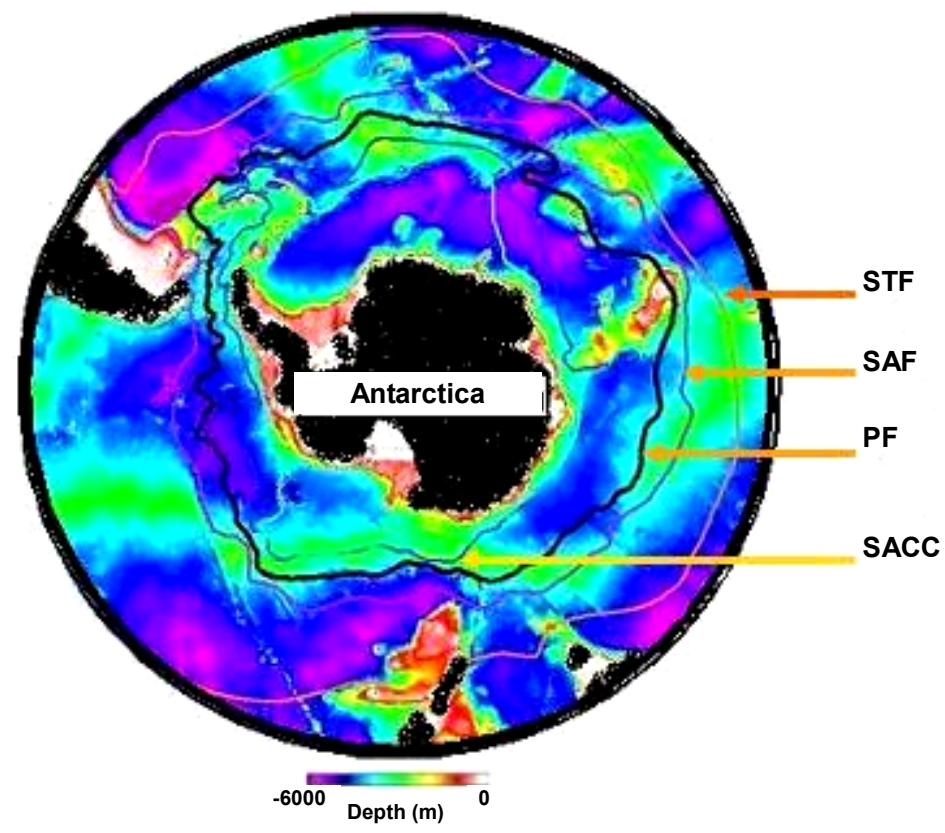

Figure 1. The geography of the study area which covers from $40^{\circ} \mathrm{S}$ to $74^{\circ} \mathrm{S}$ and from $0^{\circ} \mathrm{E}$ to $360^{\circ} \mathrm{E}$. Sea water density fronts, i.e. Sub Tropical Fronts (STF), Sub Antarctic Fronts (SAF), Polar Fronts (PF) and Sub Antarctic Counter Current (SACC) from Orsi et al. (1995) and bathymetry of the Southern Ocean is indicated. 
ice thickness and $-1.2 \% \pm 0.6 \%$ per decade for sea ice area from 1979 to 2003 [10]. In another study, [11] demonstrated positive trends in the SO zonal wind stress from 1980 to 2001 from ECMWF reanalysis (ERA40) $\left(45^{\circ} \mathrm{S}-60^{\circ} \mathrm{S}\right)$, satellite $(\mathrm{SSM} / \mathrm{I})$ winds and island station data. Furthermore, that trend had strong seasonal dependence from a max of $0.02 \mathrm{~N} \cdot \mathrm{m}^{-2} \cdot \mathrm{decade}^{-1}$ in January at $55^{\circ} \mathrm{S}$ to small values in austral winter months. There are indications that this is linked to the strengthening in the Southern Annular Mode (SAM), which demonstrates an upward trend. Later, [12] considered wind stress variability for a broad region in the SO (1979-2009) using NCEP-CFSR reanalysis and found a tendency for wind stress to increase in the NCEP-NCAR and NCEP-DOE atmospheric reanalysis but not the coupled ocean-atmosphere NCEP-CFSR reanalysis or ERA40. Many of the changes observed in the SO such as ocean circulation pattern, warmed, freshened and more acidic in recent decades have been caused by changes in wind patterns, which in turn are linked to both the ozone hole and the increase in greenhouse gases in the atmosphere [13]-[15]. In recent decades the SO circumpolar has warmed at a depth of $900 \mathrm{~m}$ (Figure 5, [16]), seasonal snow cover has decreased [17], westerlies are strengthened [11] and sea-ice extent significantly [10]. Sea ice and ice generating waves that rapidly transmit this climate signal indicate relatively little change in recent decades [14]. [18] found that the wind energy input to the ACC increased remarkably in recent decades. [19], in a paper that concentrated on evaporation and precipitation, reported a global mean trend of $0.08 \mathrm{~ms}^{-1} \cdot \mathrm{decade}^{-1}$ (from 1987 to 2006) using special sensor microwave/imager (SSM/I) data.

The above studies reveal that the changes do occur in recent decades and the close relationship between the surface winds (SW), wind stress (WS), and sea surface temperature (SST) in the SO to the climate signals is significant to understand the variability in the study region. Furthermore, the trends of these parameters have not been reported earlier. An attempt is made in the study region to address the seasonal, trends and interannual variability in the $\mathrm{SO}$ which covers swath of $30^{\circ}$ width from $40^{\circ} \mathrm{S}$ to $70^{\circ} \mathrm{S}$ globally that is from $0^{\circ} \mathrm{E}$ to $360^{\circ} \mathrm{E}$, spanning 16 years (from 1993 to 2008) of SO in recent decades. For this purpose we have used the satellite observed SW, WS over the ocean and SST in last decades. In this work we focus on interannual variability of the annual mean fields; the interannual variability in seasonal field is not considered in the current study.

\section{Data}

To understand interannual variability of the SO we need to have temporal and spatial data which is possible with the technology of satellite remote sensing. SST and Winds are directly or indirectly associated with the global climate changed. Presently long term temporal parameters are available with the CERSAT to understand climate signals in the recent decades. We used monthly mean wind speed field produced by CERSAT at the French Research Institute for exploitation of the sea (IFREMER). The product is derived from the observations of scatterometers AMI-Wind onboard the European Space Agency satellites ERS-1 (1991-1996) and ERS-2 (1996-2001), NASA scatterometers NSCAT onboard the ADEOS-1 (1996-1997), and Sea Winds onboard the Quik-SCAT (1999-2008). The CERSAT product provides wind stresses (WS) which are derived from the wind speed using the bulk formula of [20]. The original products are monthly has resolution of $0.5^{\circ} \times 0.5^{\circ}$ grid which is averaged to $1^{\circ} \times 1^{\circ}$ grid. The Quik-SCAT wind stress is the true wind stress on the sea surface, taking account the difference between the wind velocity and the surface velocity of the ocean, while the reanalysis wind stresses does not account for the effect of surface ocean currents. In addition, the differences in the bulk algorithms also contribute to the differences. The Quik-SCAT wind stress is converted from equivalent neutral-stability 10-m winds using the Large and Pond neutral stability drag coefficient [21].

The monthly-mean SST data are derived from NCEP Optimum Interpolated (OI) SST Analyses product, which has a resolution of $1^{\circ} \times 1^{\circ}$ covering the period from January 1993 to December 2008. It is merged satellite and in situ SST observations [22]. During the assimilation, the temperature at $5 \mathrm{~m}$, also referred to as the model SST, is strongly nudged to the daily OI SST [23]. [24] showed that the mean CFSR SST is about $0.05^{\circ} \mathrm{C}-0.1^{\circ} \mathrm{C}$ warmer than the daily OI SST in the tropical Indian Ocean, the western tropical Pacific and tropical North Atlantic, and they propose the warm SST biases are largely due to too strong shortwave radiation heat fluxes in those regions. Time series data made combining different satellite missions onboard the European Space Agency satellites ERS-1, ERS-2, ADEOS-1 (resolution is $1^{\circ}$ ) and Quik-SCAT (resolution $0.5^{\circ}$ ). However, there are some of the strength and weaknesses of the above data sets. Since the resolution of data sets is different, we picked up data point from Quik-SCAT on similar grid to that of ERS-1/2 to make it homogeneous.

To explain the significance and delineate the role of temporal modes of Empirical Orthogonal Function (EOF), 
we use monthly mean Antarctic Oscillation (AAO) index (http://www.cpc.ncep.noaa.gov/), which is the first leading mode from the EOF analysis of monthly mean geopotential height anomalies at $700 \mathrm{hPa}$ over the southern hemisphere. Monthly mean anomaly data were used to obtain the loading patterns. Also, monthly mean Nino 3.4 data which is the average SST anomaly in the region bounded from $5^{\circ} \mathrm{N}$ to $5^{\circ} \mathrm{S}$, from $170^{\circ} \mathrm{W}$ to $120^{\circ} \mathrm{W}$, were used. This region has large variability on El Niño time scales, and is close to the region where changes in local SST are important for shifting the large region of rainfall typically located in the far western Pacific [25].

\section{Methods}

To study the inter-annual variability using global time series of SW, WS and SST are averaged on $5^{\circ}$ latitude by $10^{\circ}$ longitude grid. The simple linear regression model is calculated from its observed values $y_{i}$ at the time $t_{i}$, $i=1,2, \cdots, n$, by fitting $\left(t_{i}, y_{i}\right)$ to a linear relation through least squares methods.

$$
v_{i}=b_{0}+b_{1} t_{i}+\varepsilon_{i} \quad i=1,2, \cdots, n
$$

where the observed values of the $y_{i}$ 's constitute the responses or values of the dependent variable, the $t_{i}$ 's are the settings of the independent variable, $b_{0}$ and $b_{1}$ are the intercept and slope (trend) parameters, respectively, and the $\varepsilon_{i}$ 's are independently distributed normal errors each with mean zero and variance $s^{2}$ based on a method described by [26], see also Appendix A [27].

To study the interannual variability, EOF was performed on the mean values and linear trends were first removed from the time series which was smoothed values through the 12-month running mean [26], the EOF analyses was performed to extract dominant patterns and their associated time coefficient functions. The record mean and linear trend are removed from each time series. Each de-meaned, de-trended time series is normalized by dividing each data series by its standard deviation. This ensures that the variances from no one station dominate the analysis and all the stations get an equal chance to contribute. The normalized time series fluctuations are the data series we used further for the EOF analyses. The total variance for each of the $M$ Eigen values = 1; thus, the total variance for all modes is given by, $\sum \lambda_{i}=M$.

To construct the $M \times N$ data matrix, $D$, using the $M$ rows (locations $x_{m}$ ) and $N$ column (time $t_{n}$ ) of the normalized data series and from this derive the symmetric covariance matrix, $C$, by multiplying $D$ by its transpose $D^{T}$.

The data series $\psi_{m}(t)=\sum_{i=1}^{M} a_{i}(t) \phi_{i m}$; where $i=1,2, \cdots, N$ and $m=1,2, \cdots, M, a_{i}(t)$ is the amplitude of the $i^{\text {th }}$ orthogonal mode at time $t=t_{n}(1,2, \cdots, N)$. Equation (1) says that the time variation of the dependent scalar variable $x(m, t)$ at each location, $m$ results from the linear combination of $M$ spatial function $\phi_{i}$, whose amplitude are weighted by $M$ times depended coefficient, $a_{i}(t), i=1,2, \cdots, M$. The weight $a_{i}(t)$ tells us how the spatial mode the $\phi_{i m}$ varies with time.

As a result, the variance in each orthogonal mode is given by

$$
\lambda_{i}=\frac{1}{N} \sum_{n=1}^{N}\left[a_{i}\left(t_{n}\right)^{2}\right]
$$

This mode is arranged in order of maximum magnitude. The total of $M$ empirical orthogonal function corresponds to $M$ eigenvalues. The $1^{\text {st }}$ mode contains the highest percentage of the total variance $\lambda_{i}$ and so on. If we add up all the total variances in all the time series we get

$$
\sum_{m=1}^{M}\left\{\frac{1}{N} \sum_{n=1}^{M}\left[\psi_{m}\left(t_{n}\right)\right]^{2}\right\}=\sum_{j=1}^{M} \lambda_{i}
$$

The total variances in the $M$ time series equation. The total variances contains in the statistical modes. The time dependent amplitude of the $i^{\text {th }}$ statistical mode is given by

$$
a_{i}(t)=\sum_{n=1}^{M} \psi_{m}(t) \phi_{i m}
$$

The eigen values of the two leading modes for the SW, WS and SST are listed in Table 2.

In addition, climatological mean (16 year averaged) monthly fields and the annual mean field for the SW, 
WSCL, and SST is also calculated. As a background fields for the trends and interannual variability, the January, July, and annual climatological mean fields are explained.

\section{Results and Discussion}

The seasonal climatological monthly mean fields and annual (ensemble) mean fields of the winds and SST are described respectively as a background field for the trends and interannual variability. The January, July, and annual climatological mean fields are given in Figures 2-4 for the SW, WSCL, and SST, respectively. Complete climatological monthly mean fields for 12 months can be found from, for example, [28] for SW and [29] for SST.

\subsection{Seasonal Variability}

Figure 2 depicts the climatological mean of SW anomalies for austral summer (Figure 2(a), January), austral winter (Figure 2(b), July), and annual mean during 2003 and 2008 (Figure 2(c)). Hereinafter austral summer and austral winter will be referred to as summer and winter, respectively. The spatial anomalies of SW during summer (winter) are negative (positive) and decreasing (increasing) sharply (gradually) on either side of $50^{\circ} \mathrm{S}$ zonal section with circular cells are located south of Australia at $120^{\circ} \mathrm{E}$ and near Drag Passage between $240^{\circ} \mathrm{E}$ and $300^{\circ} \mathrm{E}$ in January (July). The SW at the center of these cell remains cum in January and in July. The formation of this sub polar low cell could be due to the collisions of westerlies and polar easterlies results in convergence zone give rise to convective cell. The SW anomaly low cells between $40^{\circ} \mathrm{S}$ and $60^{\circ} \mathrm{S}$ zonal belt are contracts in January and expand in July, corresponding to the oceanic subtropical convergence and the polar front zone. This variability occurred owing to the tilt of the Earth's axis in orbit, the ITCZ will shift north and south. It will shift to the

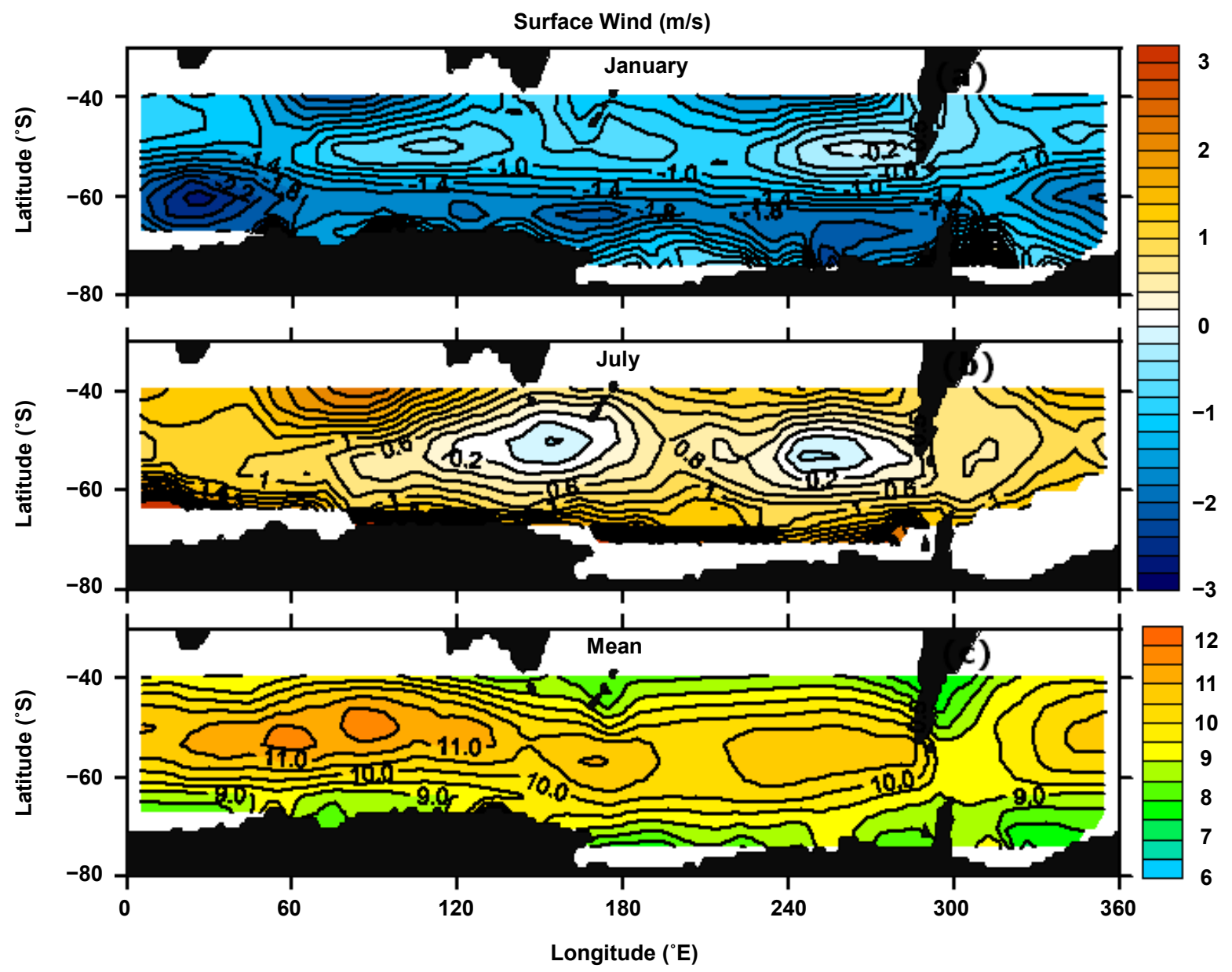

Figure 2. Climatological mean fields of the wind speed anomalies during 1993 and 2008 for (a) January, (b) July and (c) annual. 


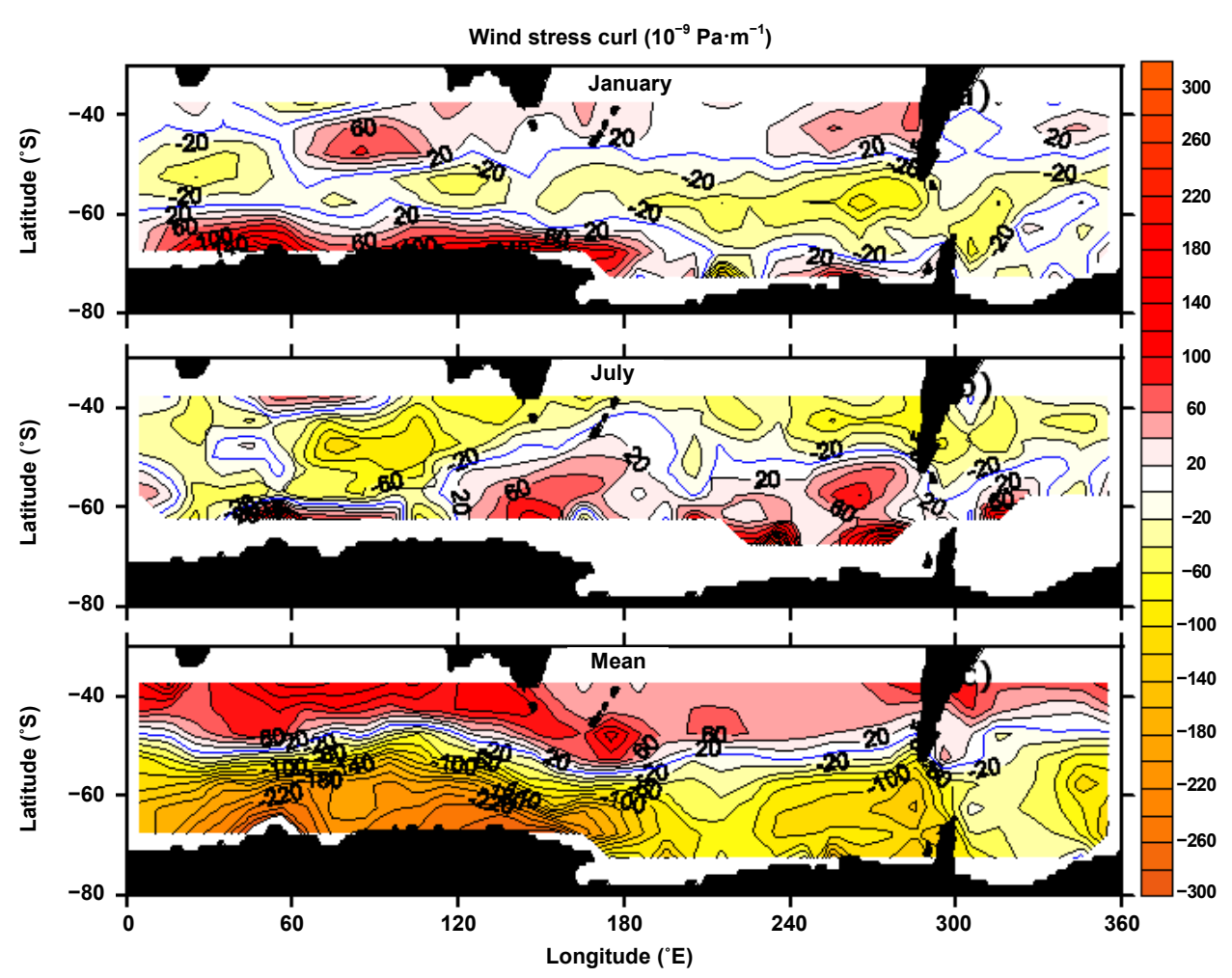

Figure 3. Climatological mean fields of winds stress curl anomalies during 1993 and 2008 for (a) January, (b) July and (c) annual.

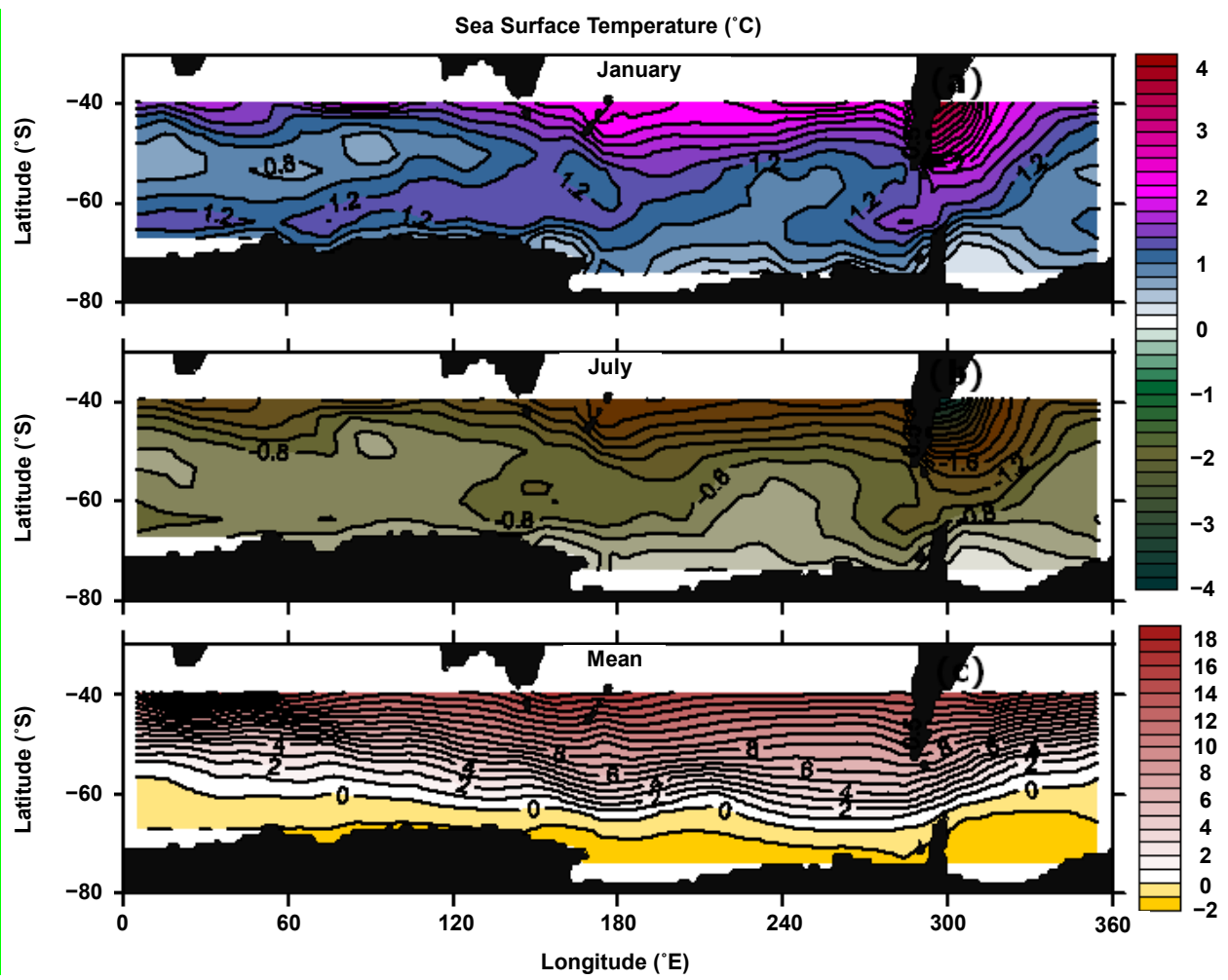

Figure 4. Climatological mean fields of sea surface temperature anomalies during 1993 and 2008 for (a) January, (b) July and (c) annual. 
south in January and north in July. Above $30^{\circ} \mathrm{S}$ latitude the wind patterned are more complex and build a conflict (divergence) between polar air and subtropical air known as the polar fronts, which is present between $50^{\circ} \mathrm{S}$ and $60^{\circ} \mathrm{S}$ zonal belt. In this region polar easterlies and westerlies together give rise to the convective current. The magnitude of the SW anomalies ranges between 0 to $-3.0 \mathrm{~m} / \mathrm{s}$ during summer and 0 to $3.0 \mathrm{~m} / \mathrm{s}$ during winter. The major features known to exist in the SW field are the subtropical anticyclonic gyres in the South Pacific, Atlantic, and Indian Oceans, year-round strong westerly surface winds over the SO that becomes positive in July. South of $40^{\circ} \mathrm{S}$, NCEP99 wind stress magnitude is typically about $35 \%$ stronger in the Indian Ocean sector of the SO [21]. This is consistent with the findings of [30]. Locally increased in wind stress magnitude in July is attributable to air-sea interaction over the meandering Agulhas Return Current, which results in locally intensified wind stress over warm water and decreased wind stress over cold water [31] [32]. The annual mean of SW speed stronger (Figure 2(c)) in polar fronts is $>11.5 \mathrm{~m} / \mathrm{s}$ and weaker towards north and south. This region is a convergence (downwelling) in nature due to westerlies and easterlies. The panels clearly show a seasonal variability in SW anomalies in the study area.

Figure 3 shows the distribution of WSCL climatology anomalies in summer (January, Figure 3(a)) and in winter (July, Figure 3(b)). In summer (Figure 3(a)), negative anomalies of WSCL occurred along $50^{\circ} \mathrm{S}$ zonal section followed by positive anomalies WSCL on either side. Also nearer to the Antarctica coast between $0^{\circ}$ to $210^{\circ} \mathrm{E}$ in the Indian sector of SO and in the south Pacific Oceans anomalies are negative. This wind field yields an anticyclonic wind stress curl where the SW anomalies are $<-1.4 \mathrm{~m} / \mathrm{s}$ (Figure 2(a)). These regions could be of upwelling in nature which is favorable conditions for generating offshore current in coastal Antarctica due to the prevailing polar easterlies (Figure 2(a)) and positive WSCL. In winter (Figure 3(b)) along $50^{\circ} \mathrm{S}$ zonal section, negative anomalies of WSCL have been shifted northward and replaced by positive anomalies of WSCL which extends more northward in south Pacific Ocean then in the Indian sector of SO. The SW yields an anticyclonic WSCL. The positive (anticyclonic) WSCL centered around $50^{\circ} \mathrm{E}, 40^{\circ} \mathrm{S}$ reflects the western location of the SIO high-pressure cell that also strengthens in this season. The annual mean of WSCL anomalies during 2003 to 2008 is shown in Figure 3(c). The annual mean of WSCL is characterized by positive (downwelling favorable) WSCL north of $50^{\circ} \mathrm{S}$ and negative (upwelling favorable) WSCL anomalies south of it leading to convergence. The line of zero WSCL anomalies denotes the limit between Indian Ocean gyre circulations, namely the cyclonic tropical gyre and the anticyclonic subtropical gyre. The negative (upwelling favorable) WSCL between $50^{\circ} \mathrm{S}$ and $60^{\circ} \mathrm{S}$ zonal belt coincide with the collision region of westerlies and polar easterlies in Figure 2.

The climatological distributions of seasonal SST anomalies are shown in Figure 4(a) for January, in Figure 4(b) for July, and annual from 2003 to 2008 in Figure 4(c). SST anomalies are warmer (cooler) then the annual mean and temperature range from $0^{\circ} \mathrm{C}$ to $4^{\circ} \mathrm{C}\left(0^{\circ} \mathrm{C}\right.$ to $\left.-4^{\circ} \mathrm{C}\right)$ in summer (winter). [33] found that warmer SST in the southwestern Indian Ocean is associated with wetter conditions over the eastern and central South Africa in austral summer. In January (Figure 4(a)) a tongue of warm anomaly entered into Indian sector of SO near to Antarctic continent from South Pacific Ocean south of Australia and another nearer to the Drag passage from South Atlantic Ocean in summer. A cold anomaly tongue from the Antarctica Drag Passage intrude along $50^{\circ} \mathrm{S}$ zonally in the Indian sector of SO and another from Antarctica in the South Pacific which proceeds north towards west coast of South America. The missing of of warm and cold waters results in strong frontal region due to mixing of two characteristics waters where found SW anomalies (Figure 2(a); Figure 2b)) are weak. In winter (Figure 4(b)) cold water spreads and extends entered SO making SST anomalies more negative in Indian, Pacific and Atlantic sector of SO. Extension of warm and cold water intrusion reduced in winter as compared to summer (Figure 4(a)) nearer to south of Australia and near to the Drage passage. The annual mean of SST (Figure $4(\mathrm{c}))$ shown increased in its temperature from south $\left(-1^{\circ} \mathrm{C}\right)$ towards north $\left(18^{\circ} \mathrm{C}\right)$. Strong temperature gradients observed north of $50^{\circ} \mathrm{S}$ between $0^{\circ}$ to $60^{\circ} \mathrm{E}$ and $310^{\circ}$ to $360^{\circ} \mathrm{E}$.

\subsection{Linear Trends}

The linear trend of a variable is calculated from its anomaly values at the times by fitting to a linear relation through least squares method. The time series anomaly mean of parameters averaged over study area is shown in Figure 5, in which the linear trends from linear regression analyses are shown with straight line. The statistical parameters such as rate of trend, standard error with $95 \%$ confidence, standard deviation, correlation coefficient and intercept listed in Table 1. Since the method of calculation is based on the 12-month means the seasonal variation is not present in the time series profiles. The SW, MC, WS, WSDV shown increasing trend (Figures 5(a)-(e); Table 1). The area-mean time series of anomalies of ZC and MC of wind and SST have linear trends 

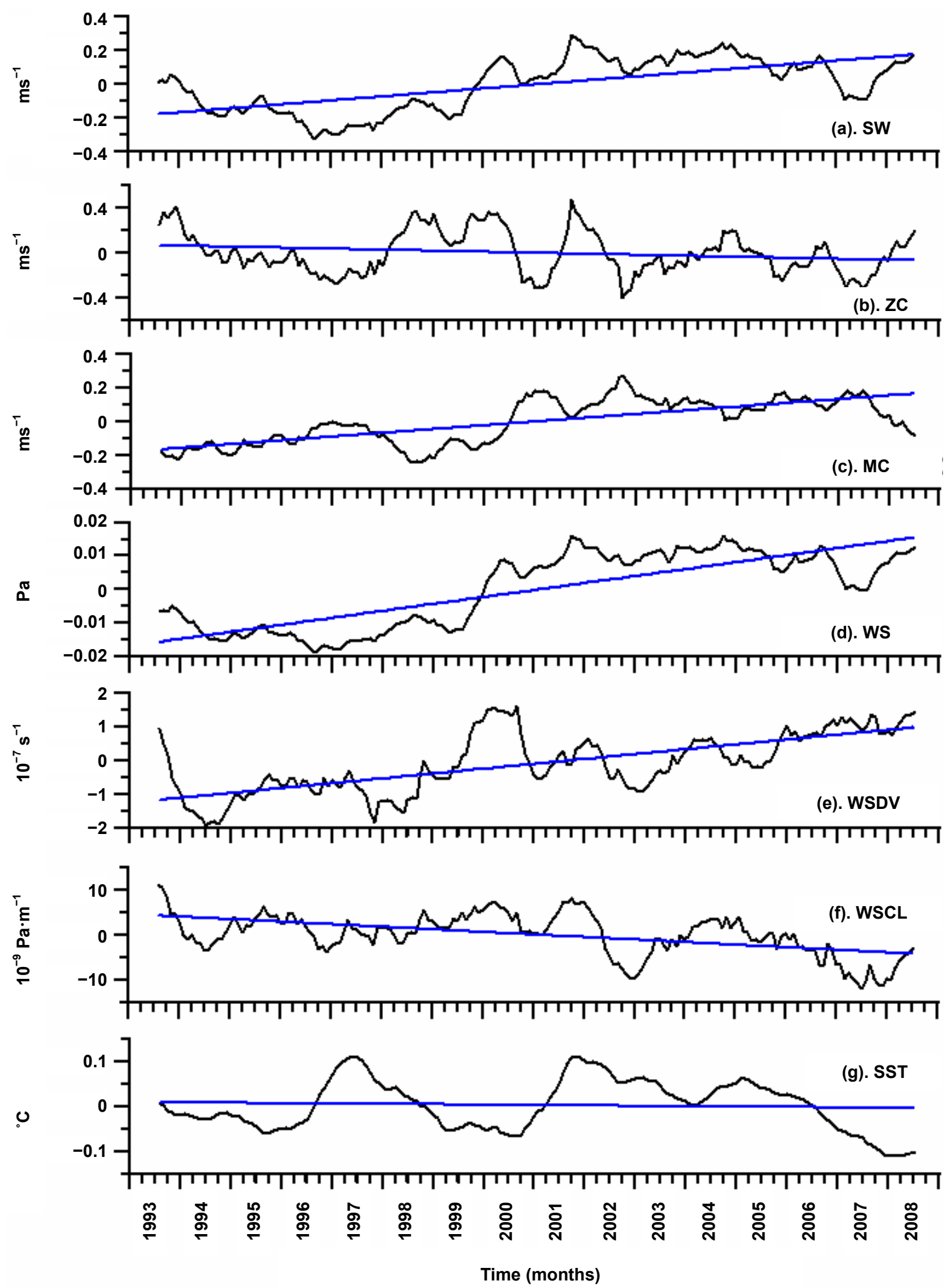

Figure 5. Time series of Southern Ocean regional area means of (a) surface winds, (b) zonal component of surface winds, (c) meridional component of surface winds, (d) wind stress, (e) wind speed divergence, (f) wind stress curl and (g) sea surface temperature. The time series anomalies are filtered through 12-month running mean. The straight solid gray line in each indicates linear trends. 
of $-0.0005 \pm 0.0003 \mathrm{~m} / \mathrm{s} /$ decade, $0.0012 \pm 0.0002 \mathrm{~m} / \mathrm{s} /$ decade and $-0.00005 \pm 0.0001^{\circ} \mathrm{C} /$ decade, respectively. The SST does not have obvious trend during 1993 and 2008 period as compared with wind parameters. Time series curve of SST shown continuous high and low peaks in 2 to 3 year interval (may be heat balanced in the SO). The SW anomalies shown increasing trend of $0.0013 \pm 0.0002 \mathrm{~m} / \mathrm{s} / \mathrm{decade}$, with the MC (ZC) exhibiting an increasing (noticeable decreasing) trend. The MC plays a critical role in heat transfer through atmospheric circulation. The WS and WSDV exhibit increasing trend whereas WSCL shown a decreasing trend could be due to decreasing trend of ZC. Correlation coefficient of ZC (Table 1) is very low as compared to other parameters which would not be playing significant role in oceanic variability. Hence it is understood that the removing seasonal variability from winds parameters and SST, there exits an interannual variability.

\subsection{Interannual Variability}

In order to understand the interannaul variability, the mean values and linear trends are first removed from the smoothed values through the 12-month running averages. The EOF analyses performed on winds parameters and SST are explained in details. The variances (eigen values) of the two leading modes for SW, WS, WSDV, WSCL and SST are listed in Table 2. The first two EOF modes of Winds parameters and SST are presented below.

\subsubsection{SW, WS and WSCL Variability}

Figures 6-8 show the Empirical Orthogonal Functions (EOFs) modes and the associated Time Correlation Function (TCFs) of the SW, WS and WSCL, respectively. The EOF-1 of SW and WS resembles each other and demonstrates convergence event which explains $19 \%$ and $25 \%$ of their total variances respectively. An eigen value of WS is higher than that of the SW. The convergence occurred above sea surface in sub-polar region due

Table 1. Linear trend with standard error of $95 \%$ confidence, standard deviations, correlation coefficient (CC) and intercept (I) for wind speed $\left(\mathrm{SW}, \mathrm{ms}^{-1}\right)$, zonal component $\left(\mathrm{ZC}, \mathrm{ms}^{-1}\right)$, meridional component $\left(\mathrm{MC}, \mathrm{ms}^{-1}\right)$, wind stress (WS, Pa), wind stress divergence (WSDV, $10^{-7} \mathrm{~s}^{-1}$ ), wind stress curl (WSCL, $10^{-9} \mathrm{~Pa} \cdot \mathrm{m}^{-1}$ ) and sea surface temperature (SST, ${ }^{\circ} \mathrm{C}$ ) during 1993 and 2008. P: parameters; STD: standard deviation; ER: errors.

\begin{tabular}{ccccccc}
\hline P & Trends & STD ER (95\%) & STD Variances & \multirow{2}{*}{ CC } & I \\
\cline { 2 - 4 } SW & & decade $^{-1}$ & & & 0.654 & -0.178 \\
ZC & 0.0013 & \pm 0.0002 & $0.106733 \%$ & & -0.206 & 0.066 \\
MC & -0.0005 & \pm 0.0003 & $0.126936 \%$ & $0.088230 \%$ & -0.167 \\
WS & 0.0012 & \pm 0.0002 & $0.00748 \%$ & 0.809 & -0.015 \\
WSDV & 0.0001 & \pm 0.00001 & $\pm 0.599977 \%$ & 0.695 & -1.194 \\
SST & 0.0080 & -0.00005 & \pm 0.0001 & $0.037519 \%$ & -0.066 & 0.009 \\
\hline
\end{tabular}

Table 2. Eigen values of the first two EOFs of the surface wind $\mathrm{ms}^{-1}$, wind stress, $\mathrm{Pa}$, Wind stress divergence, $10^{-7} \mathrm{~s}^{-1}$, wind stress curl $10^{-9} \mathrm{~Pa} \cdot \mathrm{m}^{-1}$ and sea surface temperature, ${ }^{\circ} \mathrm{C}$ of the Southern Ocean.

\begin{tabular}{|c|c|c|c|c|c|}
\hline Parameters & EOF No. & Eigen Values & Cumult. \% & $\%$ & Standard Errors \\
\hline \multirow[t]{2}{*}{ SW } & 1 & 57.26 & 0.199 & 19 & 8.096 \\
\hline & 2 & 44.59 & 0.354 & 15 & 6.305 \\
\hline \multirow[t]{2}{*}{ WS } & 1 & 72.48 & 0.252 & 25 & 10.25 \\
\hline & 2 & 41.59 & 0.396 & 14 & 5.882 \\
\hline \multirow[t]{2}{*}{ WSDV } & 1 & 30.91 & 0.108 & 10 & 4.370 \\
\hline & 2 & 26.58 & 0.200 & 09 & 3.759 \\
\hline \multirow[t]{2}{*}{ WSCL } & 1 & 32.99 & 0.115 & 11 & 4.665 \\
\hline & 2 & 30.00 & 0.219 & 10 & 4.240 \\
\hline \multirow[t]{2}{*}{ SST } & 1 & 64.04 & 0.222 & 22 & 9.050 \\
\hline & 2 & 45.97 & 0.382 & 16 & 6.502 \\
\hline
\end{tabular}



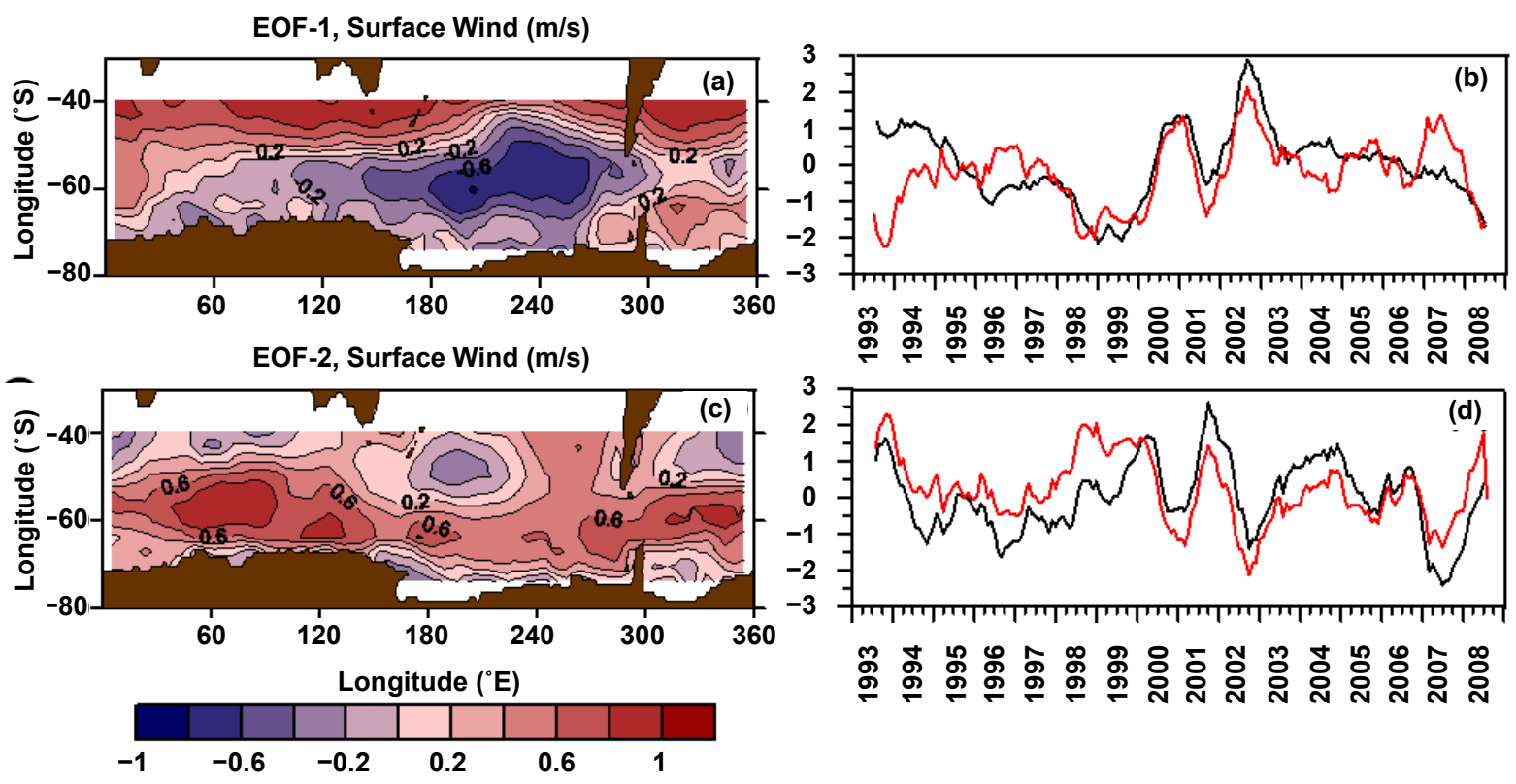

Figure 6. The first and second EOF modes of the surface winds anomaly variability. EOF-1 (a) Spatial pattern of the surface winds anomaly. (b) Time coefficient function of the surface winds anomaly (inverse AAO). EOF-2 (c) Spatial pattern of surface winds anomaly. (d) Time coefficient function of surface winds anomaly. Black lines indicate the time coefficient function; Red lines indicate the anomaly of Antarctic Oscillations (AAO) Index. All the time series are normalized.
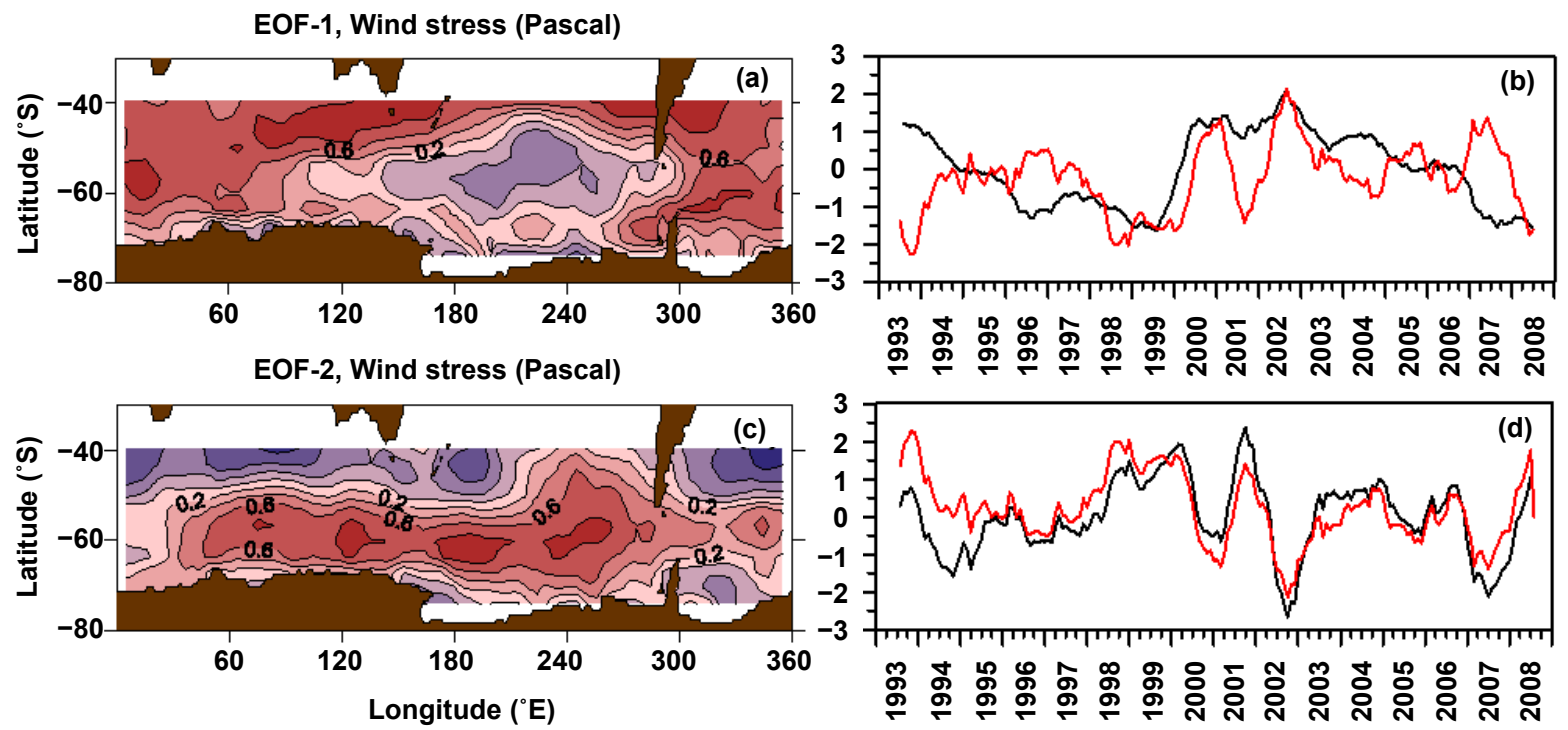

Figure 7. The first and second EOF modes of the wind stress anomaly variability. EOF-1 (a) Spatial pattern of the wind stress anomaly. (b) Time coefficient function of the wind stress anomaly (inverse AAO). EOF-2 (c) Spatial pattern of surface winds anomaly. (d) Time coefficient function of wind stress anomaly. Black lines indicate the time coefficient function; Red lines indicate the anomaly of AAO Index. All the time series are normalized.

to the collision of westerlies and polar easterlies winds developed a low pressure system. Due to collision and chilly conditions air mass rises upward and forms a convective cell. The spatial pattern in EOF-1 of SW in Figure 6(a) and WS in Figure 7(a) is characterized by low variances situated in the SO along $60^{\circ} \mathrm{S}$ meridional section between $25^{\circ} \mathrm{E}$ to the Drake Passage and it is more confined to Pacific Ocean sector of the SO bounded by high variances. Figure 8(a) shows the spatial distribution of WSCL in EOF-1 and the low variance associated with the negative variance and pocket of positive variance in the Pacific sector of SO of WSCL which explains 

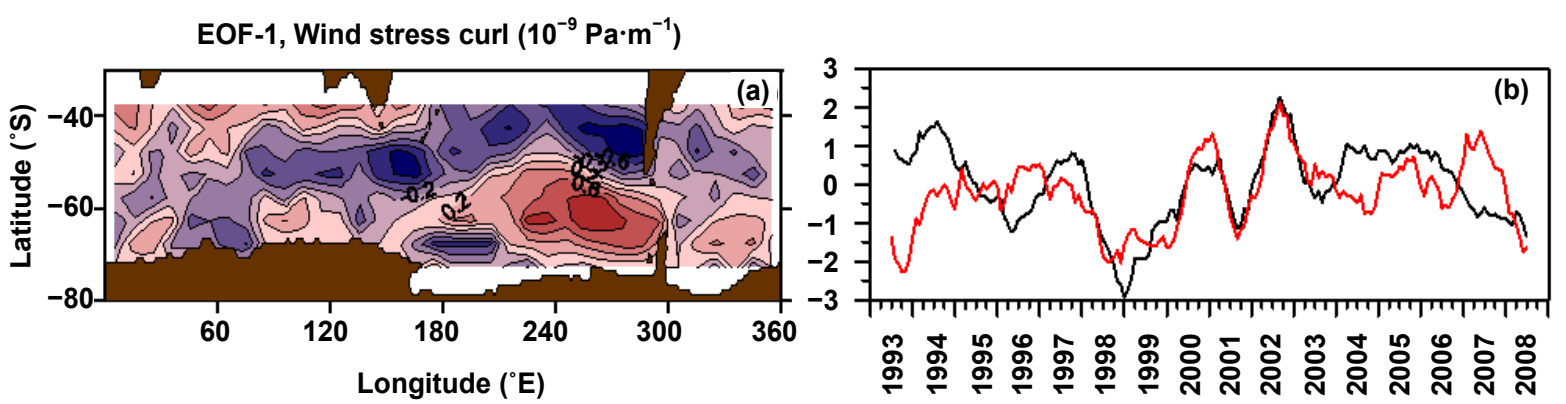

Figure 8. The first EOF modes of wind stress curl anomalies. EOF-1 (a) Spatial pattern of the wind stress curl anomaly. (b) Time coefficient function of the wind stress curl anomaly. Black lines indicate the time coefficient function; Red lines indicate the inverse anomaly of AAO Index. All the time series are normalized.

$11 \%$ of their total variances with zero lag month and lower correlation coefficient of 0.4771 and it is coincides with negative WS in Figure 7(a).

In EOF-2 the spatial pattern of SW (Figure 6(c)) and WS (Figure 7(c)) is reverse to that of EOF-1 which explains $15 \%$ and $14 \%$ of their total variances. The two mode variance is less pronounced in the Pacific sector of the SO and more pronounced in the Indian, and Atlantic sectors of the SO. In EOF-2 the sub-polar low is clearly represented throughout $\mathrm{SO}$ as low variance which represents high atmospheric pressure and high variance represent low atmospheric pressure. The spatial distribution modes of SW and WS are identical to each other as SW produced stress on the sea surface and form due to pressure difference in the atmosphere. A lagged linear regression analyses indicates that the TCFs of EOF-1 is the best correlated with the reversed Antarctic Oscillation (AAO) index (Figure 6(b), Figure 7(b) and Figure 8(b)) and EOF-2 with the AAO index (Figure 6(d) and Figure 7(d)), which is the normalized anomalies of a low frequency mode of atmospheric variability of the southern hemisphere know as the Southern Annular Mode (SAM) or Southern Hemisphere Annular Mode (SHAM) south of $20^{\circ} \mathrm{S}$. It is dominant pattern of non seasonal tropospheric circulation and characterised by atmospheric pressure. The north and south movement of the westerlies wind belt that encircle Antarctica dominating middle and higher latitudes of the SO. TCFs of SW (WS) lags the AAO by 1 (6) lag month earlier (later) leading the former in EOF-1 with moderate (lower) correlation coefficient of $0.5856(0.441)$ and zero lag month in EOF-2 with moderate correlation coefficient of SW (WS) is $0.5892(0.7442)$. There exits an interannual variability in wind parameters.

\subsubsection{SST Variability}

The spatial distribution of SST in EOF-1 (Figure 9(a)) show high variance (positive SST anomaly) node at $60^{\circ} \mathrm{S}$, $60^{\circ} \mathrm{E}-150^{\circ} \mathrm{E}$ in the Indian sector of SO and at $40^{\circ} \mathrm{S}, 240^{\circ} \mathrm{E}$ in the Pacific sector of the SO that corresponds to the low pressure regions. Low variance (negative SST anomaly) node at $70^{\circ} \mathrm{S}, 330^{\circ} \mathrm{E}$ in the Atlantic sector of SO and to the north of high variance in the Indian sector of SO that corresponds to the high pressure region which is favorable conditions for the formation of AAO and represents SAM events. The TCFs of the EOF-1 shows drop during 1993, 1998-99, and 2001 and 2008 in between period it remains positive. The EOF-2 of SST shows dipole structure of high and low variances in the Pacific Ocean sector of the SO, the nodes located at $50^{\circ} \mathrm{S}, 180^{\circ} \mathrm{E}$ and at $50^{\circ} \mathrm{S}, 270^{\circ} \mathrm{E}$; high positive variance is also evident in Indian sector of SO (Figure 9(c)). The node of high and low anomalies of SST in the Pacific Ocean sector of the SO represents El Nino/Southern Oscillation (ENSO) events. The southern Oscillation refers to changes in sea level air pressure patterns in the Southern Pacific Ocean between Tahiti and Darwin, Australia. ENSO is primarily monitored by the Southern Oscillation Index (SOI). The SST monitored in region Nino 3.4 along the equator is correlated better with the SOI. The corresponding TCFs of EOF-1 (EOF-2) is correlated with the reversed relationship with AAO (Nino 3.4) index, the earlier (latter) leading the former by 4 (9) months, which explain $22 \%(16 \%)$ of their total variances consistence with the $25 \%$ variance of WS and with maximum moderate correlation coefficient of 0.5233 (0.6389). Nino 3.4 SST index is the mean SST anomaly averaged over a central-eastern equatorial Pacific region $\left(5^{\circ} \mathrm{N}\right.$ to $5^{\circ} \mathrm{S}$, from $170^{\circ} \mathrm{W}$ to $120^{\circ} \mathrm{W}$ ) [25]. The four major peaks correspond well to the 1994-1995, 1997-1998, 2002-2003 and 2006-2007 El Nino events and three major troughs correspond well to the 1995-1996, 1998-2000 and 2007-2008 La Nino events. TCFs of the EOF-1 (Figure 9(b)) and EOF-2 (Figure 9(d)) mode shows inter-annual variability 

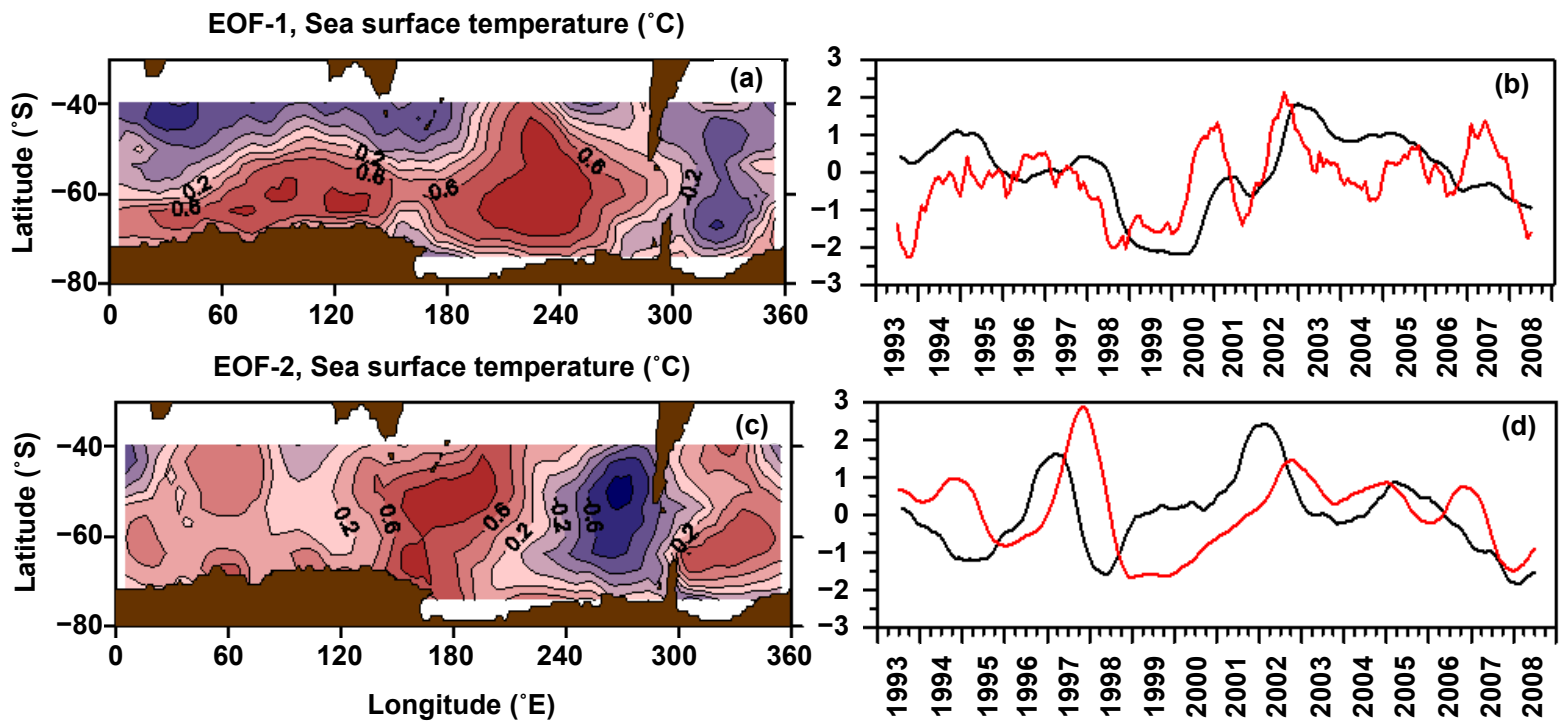

Figure 9. The first and second EOF modes of sea surface temperature anomalies. EOF-1 (a) Spatial pattern of the sea surface temperature. (b) Time coefficient function of the sea surface temperature anomaly. EOF-2 (c) Spatial pattern of the sea surface temperature anomaly. (d) Time coefficient function of sea surface temperature anomaly. Black lines indicate the time coefficient function; red lines indicate the inverse anomaly of AAO Index in (b) and Nino 3.4 Index in (d). All the time series are normalized.

after removing seasonal variability using 12 months running mean. [34] shows the strongest interannual variability of the SST in the Indian Ocean appears in the southern subtropical-extratropical region $\left(20^{\circ} \mathrm{S}-50^{\circ} \mathrm{S}\right)$, where the standard deviations of the seasonally averaged SST anomalies surpass $0.4^{\circ} \mathrm{C}$ in large areas across the basin. These SST fluctuations affect regional climate variability significantly.

\section{Summary}

In the current study we investigated seasonal changes, trends and interannual variability on the basis of satellite data during 1993 and 2008 by performing EOF analysis on SW, WS, WSCL and SST anomalies which had been passed through a 12-month running mean filter. January (July) climatology indicates weaker (stronger) SW which is coincident with slightly warmer (cooler) SST. The climatological mean of SW (16 years average) indicates zonal frontal region due to westerlies associated with positive WSCL and polar easterlies associated with negative WSCL. The area-mean time series anomalies of zonal and meridional component of SW and SST have linear trends of $-0.0005 \pm 0.0003 \mathrm{~m} / \mathrm{s} /$ decade, $0.0012 \pm 0.0002 \mathrm{~m} / \mathrm{s} /$ decade and $-0.00005 \pm 0.0001^{\circ} \mathrm{C} / \mathrm{dec}$ ade, respectively. The SW anomalies show an increasing trend of $0.0013 \pm 0.0002 \mathrm{~m} / \mathrm{s} /$ decade, with the meridional (zonal) component exhibiting an increasing (decreasing) trend. The WS and WSDV exhibit an increasing trend whereas WSCL shows a decreasing trend. The SST fluctuates close to zero with repeated high and low peaks in an interval of 2 - 3 years.EOF-1 spatial pattern of SW is characterized by low variances in the polar frontal region along $60^{\circ} \mathrm{S}$ zonal section with maximum node confined to Pacific sector of SO. EOF-2 pattern exhibits shifting of polar frontal region more southward. The time coefficient of EOF-1 of SW, WS and WSCL is correlated with reversed AAO and EOF-2 with AAO. EOF-1 TCFs of WS, SST and SW explain 25\%, 22\% and 19\% of their total variances respectively whereas EOF-2 TCFs of SST, SW and WS explain 16\%, $15 \%$ and $14 \%$ of their total variances respectively. The spatial distribution EOF-1 of SST shows high variances in the Indian sector and in the Pacific sector of the SO. The corresponding time coefficient function indicates a reversed relationship with AAO index. EOF-2 of SST shows dipole structure in the Pacific Ocean sector of the SO associated ENSO event; high positive variance is also evident in the Indian sector. The time coefficient of EOF1 (EOF-2) is correlated with inversed AAO (Nino 3.4) index, with the earlier (latter) leading the former by 4 (9) months. Based on the EOF analyses, it can be inferred that AAO and Nino 3.4 indices play an important role in modulating SW and SST changes in the SO. This work signifies that the interannual variability do exist filtering seasonal changes which could be due to the AAO and the ENSO related event as revealed by the EOF analyses 
of SST in the SO region of the Global Ocean.

\section{Acknowledgements}

The surface winds and SST were obtained from CERSAT/IFREMER and NCEP/NOAA, respectively. We acknowledge the encouragement of the NCAOR Director and Secretary, Ministry of Earth Sciences.

\section{References}

[1] Hines, K.M., Bromwich, D.H. and Marshall, G.J. (2000) Artificial Surface Pressure Trends in the NCEP/NCAR Reanalysis over the Southern Ocean and Antarctica. Journal of Climate, 13, 3940-3952. http://dx.doi.org/10.1175/1520-0442(2000)013<3940:ASPTIT>2.0.CO;2

[2] Comiso, J.C. (2000) Variability and Trends in Antarctic Surface Temperatures from in Situ and Satellite Infrared Measurements. Journal of Climate, 13, 1674-1696. http://dx.doi.org/10.1175/1520-0442(2000)013<1674:VATIAS >2.0.CO;2

[3] Kostianoy, A.G., Ginzburg, A.I., Lebedev, S.A., Frankignoulle, M. and Delille, B. (2003) Fronts and Mesoscale Variability in the Southern Indian Ocean as Inferred from the TOPEX/POSEIDON and ERS-2 Altimetry Data. Oceanology, 43, 632-642.

[4] Kostianoy, A.G., Ginzburg, A.I., Frankignoulle, M. and Delille, B. (2004) Fronts in the Southern Indian Ocean as Inferred from Satellite Sea Surface Temperature Data. Journal Marine Systems, 45, 55-73. http://dx.doi.org/10.1016/j.jmarsys.2003.09.004

[5] Lebedev, S.A. and Sirota, A.M. (2004) Application of Satellite Altimetry Data in Fish and Oceanologic Investigation in the Southeastern Pacific Ocean. Voprosu Rybolovstva (Fishering Problems), 5, 482-491. (In Russian)

[6] Lebedev, S.A. and Sirota, A.M. (2007) Oceanographic Investigation in the Southeastern Pacific Ocean by Satellite Radiometry and Altimetry Data. Advanced Space Research, 39, 203-208. http://dx.doi.org/10.1016/j.asr.2006.11.002

[7] Moore, B., Quinn, T., Governato, F., Stadel, J. and Lake, G. (1999) Cold Collapse and the Core Catastrophe. Monthly Notices of the Royal Astronomical Society, 310, 1147-1152. http://dx.doi.org/10.1046/j.1365-8711.1999.03039.x

[8] Sirota, A.M., Lebedev, S.A. and Kostianoy, A.G. (2004) Oceanic Currents in the Southeastern Pacific Ocean as Revealed by Satellite Altimetry Data. Gayana, 68, 539-542.

[9] Fu, L.L. and Chelton, D.B. (1984) Temporal Variability of the Antarctic Circumpolar Current Observed from Satellite Altimetry. Science, 226, 343-346. http://dx.doi.org/10.1126/science.226.4672.343

[10] Comiso, J.C. (2004) The Polar Ice Cover-How It Is Changing. Gayana, 68, 123.

[11] Yang, X.Y., Huang, R.X. and Wang, D.X. (2007) Decadal Changes of Wind Stress over the Southern Ocean Associated with Antarctic Ozone Depletion. Journal of Climate, 20, 3395-3410. http://dx.doi.org/10.1175/JCLI4195.1

[12] Xue, Y., Huang, B., Hu, Z.-Z., Kumar, A., Wen, C., Behringer, D. and Nadiga, S. (2010) An Assessment of Oceanic Variability in the NCEP Climate Forecast System Reanalysis. Climate Dynamics, 37, 2541-2550.

[13] Gille, S.T. (2008) Decadal-Scale Temperature Trends in the Southern Hemisphere Ocean. Journal of Climate, 21, 4749-4765. http://dx.doi.org/10.1175/2008JCLI2131.1

[14] Boning, C.W., Dispert, A., Visbeck, M., Rintoul, S.R. and Schwarzkopf, F.U. (2008) The Response of the Antarctic Circumpolar Current to Recent Climate Change. Nature Geoscience, 1, 864-869. http://dx.doi.org/10.1038/ngeo362

[15] Meijers, A.J.S., Bindoff, N.L. and Rintoul, S.R. (2011) Frontal Movements and Property Fluxes: Contributions to Heat and Freshwater Trends in the Southern Ocean. Journal Geophysical Research, 116, 1-17.

[16] Gille, S.T. (2002) Warming of the Southern Ocean since the 1950s. Science, 295, 1275-1277. http://dx.doi.org/10.1126/science.1065863

[17] Fox, A.J. and Cooper, A.P.R. (1998) Climate-Change Indicators from Archival Aerial Photography of the Antarctic Peninsula. Annals of Glaciology, 27, 636-642.

[18] Huang, R.X., Wang, W. and Liu, L.L. (2006) Decadal Variability of Wind Energy Input to the World Ocean. Deep Sea Research Part II, 53, 31-41. http://dx.doi.org/10.1016/j.dsr2.2005.11.001

[19] Wentz, F.J., Ricciardulli, L., Hilburn, K. and Mears, C. (2007) How Much More Rain Will Global Warming Bring? Science, 317, 233-235. http://dx.doi.org/10.1126/science.1140746

[20] Smith, S.D. (1988) Coefficients for Sea Surface Wind Stress, Heat Flux, and Wind Profiles as a Function of Wind Speed and Temperature. Journal of Geophysical Research, 93, 15467-15472. http://dx.doi.org/10.1029/JC093iC12p15467

[21] Risien, C.M. and Chelton, D.B. (2008) A Global Climatology of Surface Wind and Wind Stress Fields from Eight 
Years of Quick-SCAT Scatterometer Data. Journal Physical Oceanography, 38, 2379-2413. http://dx.doi.org/10.1175/2008JPO3881.1

[22] Reynolds, R.W. and Smith, T.M. (1994) Improved Global Sea Surface Temperature Analyses Using Optimum Interpolation. Journal of Climate, 7, 929-948. http://dx.doi.org/10.1175/1520-0442(1994)007<0929:IGSSTA>2.0.CO;2

[23] Reynolds, R.W., Smith, T.M., Liu, C., Chelton, D.B., Casey, K.S. and Schlax, M.G. (2007) Daily High-Resolution Blended Analyses for Sea Surface Temperature. Journal of Climate, 20, 5473-5496. http://dx.doi.org/10.1175/2007JCLI1824.1

[24] Wang, W., Xie, P., Yoo, S.H., Xue, Y., Kumar, A. and Wu, X. (2011) An Assessment of the Surface Climate in the NCEP Climate Forecast System Reanalysis. Climate Dynamic, 37, 2511-2539. http://dx.doi.org/10.1007/s00382-010-0935-7

[25] Trenberth, K.E. (1997) The Definition of El Nino. Bulletin of American Meteorology Society, 78, 2771-2777. http://dx.doi.org/10.1175/1520-0477(1997)078<2771:TDOENO >2.0.CO;2

[26] Emery, W.J. and Thomson, R.E. (2001) Data Analysis and Methods in Physical Oceanography. Elsevier, New York.

[27] Fang, G., Chen, H.Y., Wei, Z.X., Wang, Y.G., Wang, X.Y. and Li, C.Y. (2006) Trends and Interannual Variability of the South China Sea Surface Winds, Surface Height, and Surface Temperature in the Recent Decade. Journal of Geophysical Research, 111, 1-16. http://dx.doi.org/10.1029/2005JC003276

[28] Liang, W.D., Jan, J.C. and Tang, T.Y. (2000) Climatological Wind and Upper Ocean Heat Content in the South China Sea. Acta Oceanography Taiwan, 38, 91-114.

[29] Chu, P.C., Lu, S. and Chen, Y. (1997) Temperature and Spatial Variability of the South China Sea Surface Temperature Anomaly. Journal of Geophysical Research, 102, 20937-20955. http://dx.doi.org/10.1029/97JC00982

[30] Josey, S.A., Kent, E.C. and Taylor, P.K. (2002) Wind Stress Forcing of the Ocean in the SOC Climatology: Comparisons with the NCEP-NCAR, ECMWF, UWM/COADS, and Hellerman and Rosenstein Datasets. Journal of Physical Oceanography, 32, 1993-2019. http://dx.doi.org/10.1175/1520-0485(2002)032<1993:WSFOTO >2.0.CO;2

[31] O'Neill, L.W., Chelton, D.B. and Esbensen, S.K. (2003) Observations of SST-Induced Perturbations of the Wind Stress Field over the Southern Ocean on Seasonal Time Scales. Journal of Climate, 16, 2340-2354. http://dx.doi.org/10.1175/2780.1

[32] O’Neill, L.W., Chelton, D.B., Esbensen, S.K. and Wentz, F.J. (2005) High-Resolution Satellite Measurements of the Atmospheric Boundary Layer Response to SST Variations along the Agulhas Return Current. Journal of Climate, 18, 2706-2723. http://dx.doi.org/10.1175/JCLI3415.1

[33] Mason, S.J. (1995) Sea Surface Temperature-South African Rainfall Associations, 1910-1989. International Journal of Climatology, 15, 119-135. http://dx.doi.org/10.1002/joc.3370150202

[34] Huang, B. and Shukla, J. (2007) Interannual SST Variability in the Subtropical and Extratropicl Southern Ocean. Technical Report 223, Center for Ocean-Land-Atmosphere Studies, Calverton, 20. 
Scientific Research Publishing (SCIRP) is one of the largest Open Access journal publishers. It is currently publishing more than 200 open access, online, peer-reviewed journals covering a wide range of academic disciplines. SCIRP serves the worldwide academic communities and contributes to the progress and application of science with its publication.

Other selected journals from SCIRP are listed as below. Submit your manuscript to us via either submit@scirp.org or Online Submission Portal.
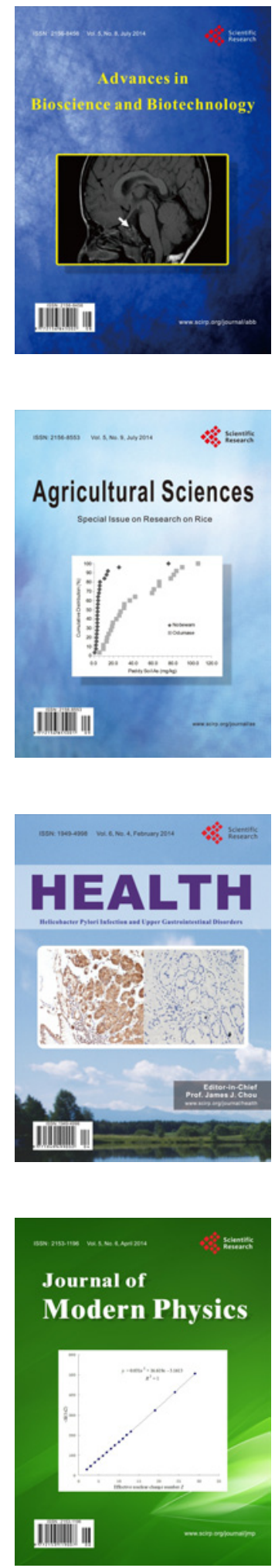
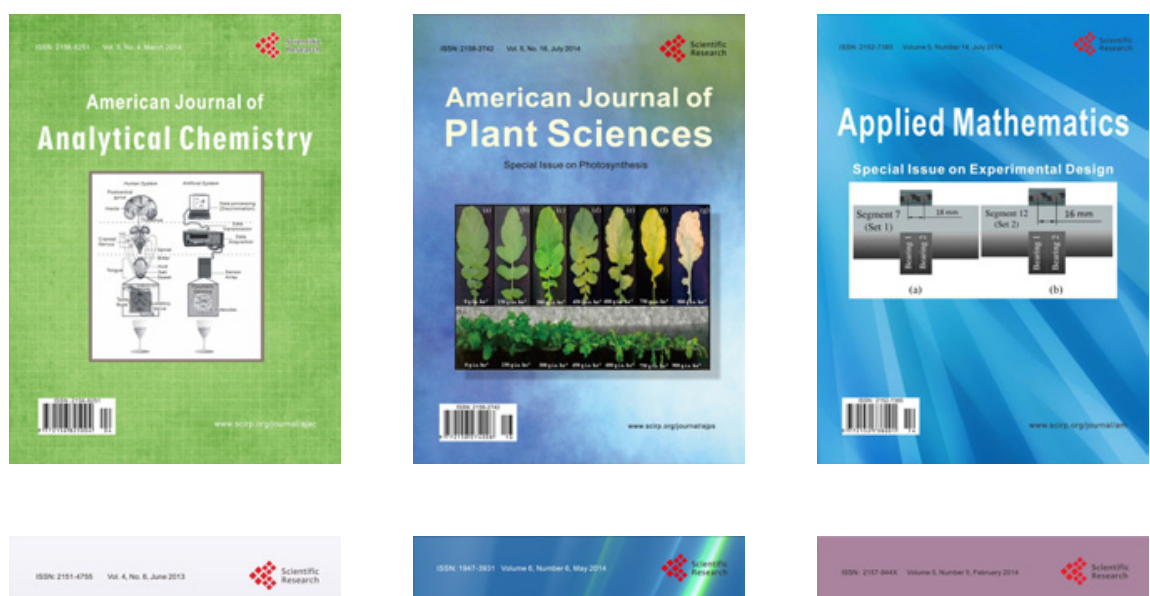

Creative Education
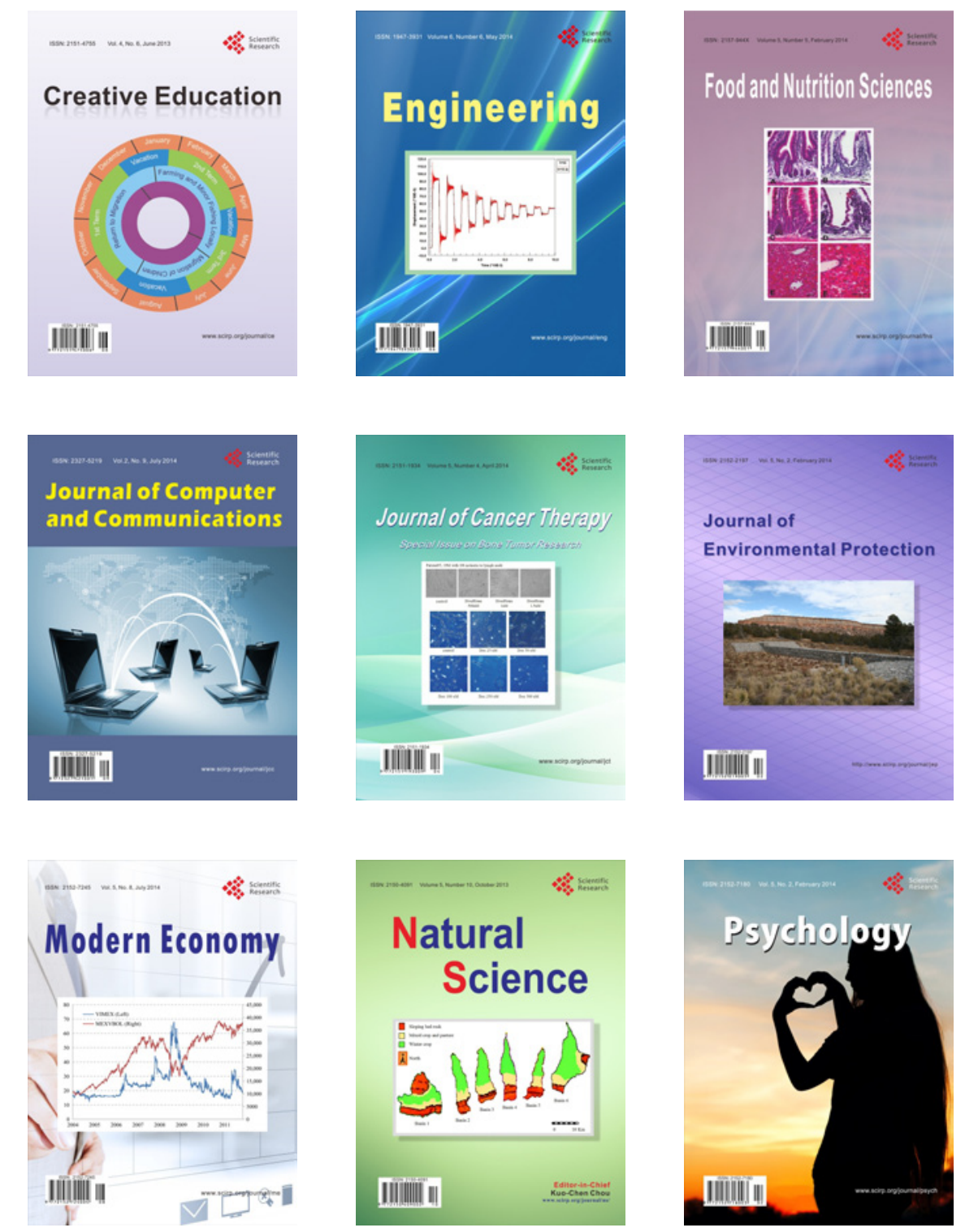